\title{
When Misery and Metaphysics Collide: William James on 'the Problem of Evil'
}

\author{
EMMA K. SUTTON*
}

Keywords: William James; Evil; Absolute Idealism; Metaphysics; Religion

William James is often described as one of America's foremost philosophers and the founder of American psychology. During the second half of the nineteenth century and the first decade of the twentieth century he published several key texts on a broad range of topics, including the psychology of religion, ethics, epistemology and metaphysics. Many are still in current use, and contemporary philosophers continue to pore over them. Biographers, meanwhile, happily speculate on everything from James's parental relationships to the state of his marriage. However, there has been relatively little detailed exploration of how James's published writings and his private life may have intersected. This article explores one such intersection: that between James's protracted experience of ill health and the elaboration of the notion of evil in his writings.

Any perusal, however perfunctory, of the thousands of letters written by James that are still in existence, cannot fail to miss his repeated references to his health, or lack of it. He certainly was not one to suffer in silence, and it is clear that, for much of his life from his early adulthood onward, he considered himself a confirmed invalid. His references to his health cover a variety of different ailments. In the 1860s, when James was in his twenties, he was plagued by everything from a bad back, to melancholy and constipation. These symptoms have not escaped the attention of his biographers; most, however, have brought to them Freudian-inspired schema. Daniel Bjork, for example, suggests that James's ongoing problems with back pain had something to do with the unfulfilled sexual urges of a young man. He reminds us that once James was married, few such back complaints continued. ${ }^{1}$ Similarly, Howard Feinstein 'explains' James's constipation with reference to psychoanalytic theory, calling attention to the same condition suffered by his brother Henry, the novelist. According to Feinstein, the two brothers found it difficult to sever their suffocatingly close fraternal bond - an event that was reminiscent of their original 'separation crisis' from their parents. That ordeal, moreover, is held to be inherently linked to the brothers' acquisition of sphincter control for the first time. Thus we should not be surprised that a later fraternal separation crisis was accompanied by a symbolic re-enactment of this bowel control process which manifested itself as constipation, concludes Feinstein. ${ }^{2}$

(C) Emma K. Sutton, 2011.

* Emma K. Sutton, PhD student, The Wellcome Trust Centre for the History of Medicine at UCL, 183 Euston Road, London NW1 2BE, UK.

Email: Emma.Sutton@ucl.ac.uk
${ }^{1}$ Daniel W. Bjork, William James: The Centre of his Vision (Washington, DC: American Psychological Association, 1997), 81.

${ }^{2}$ Howard M. Feinstein, Becoming William James (Ithaca, NY: Cornell University Press, 1999), $229 \mathrm{fn}$. 


\section{Emma K. Sutton}

Another James scholar, Donald Capps, diagnoses James's particular brand of melancholy according to the 1994 edition of the American Psychiatric Association's Diagnostic manual. ${ }^{3}$ While all historical narratives are contingent, these seem more contingent than others, rooted as they are in various anachronistic analytical frameworks.

Discarding the question of how we can 'make sense' of James's illnesses opens up another, more profitable set of questions: how might James himself have understood his symptoms? What are the terms and theoretical frameworks that he used to describe and explain his ill health to himself and others? What were the consequences? One advantage of this approach is that it avoids a particularly unhelpful assumption implicit in much of the James scholarship to date, that James's ill health can somehow be separated off from his intellectual work, that we are free to diagnose him as we wish and then put that part of his life, his ill health, to one side. An alternative is to argue that James's experience of illness was inextricably entwined with many of the major themes that run throughout his intellectual work. One such, which is present in many of his published writings, and which I shall focus on here is 'the problem of evil'.

What James meant by this was that, in any given philosophical system, 'evil facts are a genuine portion of reality', ${ }^{4}$ not something that can simply be dismissed or sidelined; they have to be accounted for. Discussion of the stubborn presence of evil, and its implications, features in many of his writings, including some of his best known: The Varieties of Religious Experience (1902), Pragmatism (1907), and A Pluralistic Universe (1909). James was convinced that 'evil' was something to which most of his fellow philosophers paid too little attention and it was his obstinate refusal to follow suit that marked his metaphysics out from most of the competition. At the turn of the twentieth century, many of his colleagues were supporters of monistic or 'absolute idealism'. 5 Essentially, their metaphysical systems rested on the belief that all the elements in the universe contribute to some sort of unified and rational system, and that there is, ultimately, a benign grand plan underlying 'the kosmos' and all its events. ${ }^{6}$ For James though, the existence of real evil meant that such metaphysical assumptions were fundamentally flawed. One of the key facets of his metaphysics was that the universe is pluralistic not monistic; 'an aggregate or collection of higher and lower things and principles ${ }^{7}$ within which any god or benevolent spiritual agency is only one entity amongst many. The reason James gave for this was the existence of evil - if God is

\footnotetext{
${ }^{3}$ Donald E. Capps, “"That Shape Am I": The Bearing of Melancholy on the Varieties of Religious Experience' in idem (ed.), Men, Religion and Melancholia (Berkeley, CA: Yale University Press, 1997), 29, 34-5, 68-9.

${ }^{4}$ William James, The Varieties of Religious Experience (Cambridge, MA: Harvard University Press, 1985), 136.

5 James saw himself, and a select few colleagues, as a band of renegade fighters assailing a philosophical enemy stronghold. For example, in a letter to one such fellow pluralist, Ferdinand Canning Scott Schiller in 1896, James wrote: 'I can foresee a more or less systematic siege of monism \& absolutism on my own part for the rest of my days (so far as I may retain ability to do anything).' William James to Ferdinand Canning
}

Scott Schiller, 15 September 1896, in Ignas K. Skrupskelis and Elizabeth M. Berkeley (eds), The Correspondence of William James, Vol. 8

(Charlottesville, VA: University of Virginia Press, 2000), 203. Note also the characteristic reference to his feared incapacity for work as a result of his chronic invalidism.

${ }^{6}$ In James's Hibbert Lectures, entitled $A$

Pluralistic Universe, the exponents of monistic idealism that he singles out as his chief adversaries are Rudolf Hermann Lotze, Josiah Royce and Francis Herbert Bradley: William James, 'A Pluralistic Universe', Ralph Barton Perry (ed.), Essays in Radical Empiricism and a Pluralistic Universe (New York: E.P. Dutton \& Co., 1971).

${ }^{7}$ James, op. cit. (note 4), 113. 


\section{When Misery and Metaphysics Collide}

infinite, then He must also be ultimately responsible for this 'excrementitious stuff' ${ }^{8}$ of the universe, and thereby lies a puzzle: If 'the absolute' is omnipotent, a being 'upon which nothing alien can be forced, [why has it] spontaneously chosen from within to give itself the spectacle of all that evil rather than a spectacle with less evil in it? ${ }^{, 9}$ As far as James was concerned, the solution to this conundrum was that "the only God worthy of the name must be finite, ${ }^{10}$ and therefore relieved of responsibility for the evil parts of the world.

Many James scholars have examined James's rejection of monism, and the technical arguments that he used to dispute this dominant philosophical position. ${ }^{11}$ What has been neglected, however, is his motive: the role that evil played in James's thinking and what it meant to him. In order to address this, I submit, it is necessary to return to the subject of James's experiences of ill health as recorded in his personal papers. One such source is a letter sent by James to his brother Henry in 1869. This was when Henry was in the midst of one of his acute and persistent attacks of constipation. William had also been suffering (for several years by this point) from the serious back problems that he believed incapacitated him and, as he saw it, put pay to many of his potential career options. Two years earlier he had travelled as far afield as Europe, to try various fashionable water cures. But it was to no avail. In his letter to Henry, James had commiserated with his brother about his health problems and proceeded to bemoan their respective sickly predicaments from a metaphysical perspective: 'For what purpose we are thus tormented I know not, - I don't see that Father's philosophy explains it any more than any one else's If there is to be evil in the world at all, I don't see why you or I should not be its victims as well as any one else the trouble is that there should be any.' 12

Illness and evil were thus entangled for James, if not synonymous, as he struggled to account for them both in a meaningful, philosophical sense. His diaries and other letters around this time contain several references to evil and how it can be reconciled within various metaphysical systems. James writes, for example, about how he has been reading Homer and trying to comprehend how the Greeks accounted for evil in their world. ${ }^{13}$ The timing of these musings seems significant. Evil first begins to inveigle its way into James's diary in the spring of 1868 , six months into his fruitless and dispiriting tour of Continental health resorts and a year after he first developed his debilitating back pain. There are also numerous other allusions to the relationship between evil and illness extant within the James corpus, written over the following months and years. In 1869, for example, James wrote to his brother, Robertson, with the intention of dissuading him from making what he saw as a bad marriage choice. Robertson and his future wife both suffered from the serious back pain that had caused James such problems and his concern was that their children would inherit the condition. Since James had trained as a doctor, he

\footnotetext{
${ }^{8}$ Ibid.

${ }^{9}$ James, op. cit. (note 6), 177-8.

${ }^{10}$ Ibid., 181.

${ }^{11}$ They have focused, in particular, on James's debt to Charles Renouvier, another nineteenth-century philosopher. See Ralph Barton Perry, The Thought and Character of William James: Volume I. Inheritance and Vocation (Oxford: Oxford University Press, 1935), 659.

${ }^{12}$ William James to Henry James Jr, 25 October 1869, in Ignas K. Skrupskelis and Elizabeth M. Berkeley (eds), The Correspondence of William
}

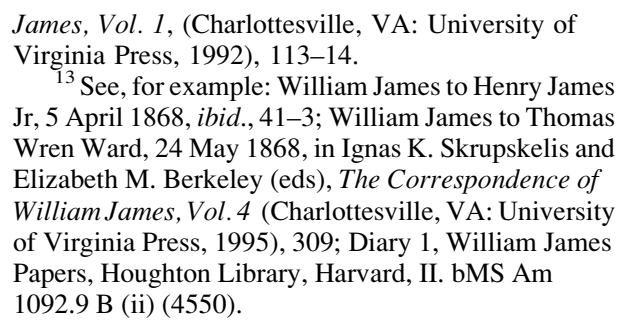

${ }^{13}$ See, for example: William James to Henry James Jr, 5 April 1868, ibid., 41-3; William James to Thomas Wren Ward, 24 May 1868, in Ignas K. Skrupskelis and Elizabeth M. Berkeley (eds), The Correspondence of William James, Vol. 4 (Charlottesville, VA: University of Virginia Press, 1995), 309; Diary 1, William James Papers, Houghton Library, Harvard, II. bMS Am 1092.9 B (ii) (4550). 


\section{Emma K. Sutton}

was well acquainted with the contemporary literature on the hereditary nature of various conditions. He wrote: '. . feeling as strongly as I do that the greater part of the whole evil of this wicked world is the result of infirm health, I account it as a true crime against humanity for anyone to run the probable risk of generating unhealthy offspring. ${ }^{14}$ The passage is striking in that it implies that James did not consider infirmity to be merely one evil among many, it was, rather, the ultimate evil, single-handedly responsible for the majority of the world's wickedness. Similarly, in one note to himself, he discusses various ways of dealing with evil and cites the specific examples of toothache, and 'the pox' or syphilis. James makes clear that, for him, the concept of evil is not simply some sort of abstract entity. Evil, he declares in the note, is something that has 'taken permanent body $\&$ actually sat down in me to stay'. ${ }^{15}$ It is not difficult to conclude therefore that the reason why the concept of evil plays such a significant role in James's published writings is because of his belief that it had taken hold of him personally, in the form of illness.

Jamesian scholarship largely conceals and distorts this rich and revealing dialogue between James's private suffering and his public writings. It is only by looking to James's personal papers, and reading his accounts of his ill health that it becomes clear that the categories of 'illness' and 'evil' were mutually constituted in James's thinking. To attempt to separate these two therefore short-changes any understanding of his work. This observation explains, at least in part, why James vehemently rejected monistic or absolute idealism at a time when it was revered by most of his colleagues. '[M]ost philosophers seem either to forget... or disdain... too much ever to mention [that there are] elements of the universe which may make no rational whole in conjunction with the other elements ...- so much "dirt" as it were. ${ }^{16}$ James, on the other hand, knew of evil that could not be ignored. In his lectures, The Varieties of Religious Experience, for example, he depicts the experience of 'insane melancholia': 'the grisly blood-freezing, heart-palsying sensation of [evil] close upon one, and no other conception or sensation able to live for a moment in its presence. ${ }^{17}$ Evil, for James, was not a dusty metaphysical curiosity or merely an occupational hazard for the serious philosopher, but something that had the power to possess him, a constant shadow cast over his intellectual endeavours.

\section{Acknowledgements}

I would like to acknowledge the studentship funding, provided by The Wellcome Trust Centre for the History of Medicine at UCL, without which the research for this paper would not have been possible. I would also like to thank my supervisor, Sonu Shamdasani, for his ongoing support and encouragement. In addition, I am very grateful to James William Anderson, whose invaluable help with locating one particular set of archival sources was much appreciated, and the James estate for permission to cite these family papers.

\footnotetext{
${ }^{14}$ William James to Robertson James, 14 November 1869, ibid., 389.

${ }^{15}$ Miscellaneous notes, William James Papers, Houghton Library, Harvard, II. bMS Am 1092.9, A (ii), (4473).

${ }^{16}$ James, op. cit. (note 4), 113-14.

${ }^{17}$ Ibid., 135. In an 1874 review of the alienist Henry Maudsley's work, James implies that he
}

\author{
believes that "no evil seems worthy of that name \\ when compared to the evil of insanity': William \\ James, 'Recent Works on Mental Hygiene (1874)', \\ F.H. Burkhardt, F. Bowers and I.K. Skrupskelis (eds), \\ The Works of William James: Essays Comments and \\ Reviews (Cambridge, MA: Harvard University Press, \\ 1987), 277.
}

